\title{
FINANCING STRATEGIES FOR NEW VENTURES: A LOOK AT SOCIAL MEDIA
}

\author{
Kim Tu, California State University, Fullerton, California, USA \\ Peng Chan, California State University, Fullerton, California, USA \\ Lam Nguyen, Bloomsburg University of Pennsylvania, Pennsylvania, USA
}

dx.doi.org/10.18374/EJM-13-4.14

\begin{abstract}
Entrepreneurs face significant challenges today when looking to start a new small business venture. One of the biggest challenges is securing the capital needed to fund the new venture. With the recent challenges in our economy, securing financing through a traditional route has become a much more difficult task and many entrepreneurs get stuck at this stage in launching a new venture. This article will discuss the traditional methods and alternative methods in obtaining capital to start a new venture and offer a supplemental financing method to obtain the capital needed by using social promotions daily deal companies such as Groupon and LivingSocial. This paper will investigate whether or not utilizing social promotion daily deal companies will be a viable source of capital for a new venture. It will also offer strategies an entrepreneur should take when deciding whether this route would work for the business they want to launch. This paper seeks to examine whether using social promotion daily deal companies could be a viable option to producing capital needed to start a new small business venture.
\end{abstract}

Keywords: New Venture Financing; Social Media 